\title{
The Interaction Between Dynamic Marketing Capability and Service Innovation Capability on Performance
}

\author{
Evo Sampetua Hariandja \\ Business School, Department of Management \\ Universitas Pelita Harapan \\ Tangerang, Indonesia \\ evo.hariandja@uph.edu
}

\begin{abstract}
This study examines the interaction between dynamic marketing capabilities, service innovation capability on performance in the context of hotel industry. The conceptual framework used in this research has been drawn from marketing and innovation theory. Specifically, relationships related to dynamic marketing capability, service innovation capability, marketing communication, and performance have been identified. This research develops a framework about interaction both capabilities and its performance in an organization and link four main variables: service innovation capability, dynamic marketing capability, marketing communication, and performance. This link has been given little attention by prior research particularly in the hospitality industry. The proposed model is discussed in the paper.
\end{abstract}

Keywords-dynamic marketing capability, service innovation capability, interaction, performance, hotel industry

\section{INTRODUCTION}

Research into the interaction of capability amongst marketing and innovation has generally been dismissed (1). Innovation capability has turned into a basic segment of an association's marketing capability on the off chance that it plans to keep up its long haul performance (2). A study led by (3) and (4) reasoned that long haul achievement is not guaranteed by innovation as it were. A firm will probably influence its innovation capacities in the event that it has better market-related capacities in adjusting its market, new market passage, and customers with more noteworthy quality. Under the idea of corresponding capability, joining the abilities results in improving an association's performance (5).

Late studies have demonstrated that a capability collaboration amongst marketing and innovation influences performance-based customers (6); (3). In this setting, marketing and innovation are seen as corresponding to enhance a synergistic business sector performance. The investigation of the capability collaboration amongst innovation and marketing has still not been investigated in particular, particularly in the friendliness business. A study led on manufacturing firms by $(7,8)$ has demonstrated that integral capability amongst innovation and marketing is decidedly related with performance. Between utilitarian coordination and collaboration amongst marketing and innovation can exist in the sharing of business sector data that is essential for considerably new service advancement in the service setting
(9), (10). This concentrate subsequently intends to investigate the aforementioned research crevice by means of two exploration destinations: to make a system portraying how dynamic marketing capability and service innovation capability can impact the performance and to examine the capability connection that can be defined in a neighborly setting keeping in mind the end goal to accomplish performance with marketing communication as moderating variable.

\section{LITERATURE REVIEW}

\section{A. Dynamic Marketing Capability}

The idea of marketing capability in the market has numerous implications and measurements. Marketing capability is characterize as the way toward coordinating the organizations, which utilize the organization's assets and aptitudes to comprehend the necessities of clients to make distinctive sorts of items identified with the opposition and get the brand prevalence (11), (12), (5) and implies the capacity of the organization to the joining of learning, abilities and procedures to address the issues of clients and manufacture a market opportunity superior to anything contenders (13) and utilizations asset to relate with clients and can prompt "market sensing" capacities (14). In (15) propose the capacity to present a dynamic market that empowers organizations to grow new items for the business in light of science. The marketing capacity can be made by the staffs utilize their insight and aptitudes in marketing prompting the opposition capacity that progressions dynamically. In (16), characterize dynamic capacities with the organization's capacity to produce restoration incorporated change and design abilities, both inside and outside to manage the changing environment rapidly. Numerous researchers have proposed the idea of a dynamic marketing capacities by coordinating marketing ideas and dynamic abilities. For instance, (15) brought up that the market limit, dynamic assets, marketing and incorporation of the information of the market to make and use to react to changes in innovation and marketing. Besides, (17) propose that the marketing abilities have an effect to the formation of business quality. Along these lines, this study augments the earlier research of dynamic marketing capability containing three measurements, which are market sensing, market learning, market targeting and positioning. 


\section{B. Service Innovation Capability (SIC)}

Service innovation is defined as a new or significantly improved service concept that is taken into practice (18). According to (19) stated that service innovation is the variations in product delivery that cause an appreciation in the service experience for consumers. This study adopts the study of (20) that SIC contains sensing, seizing, and transformation components. Sensing refers to the identification of the need to change service operations or opportunities; seizing refers to exploring and selecting feasible opportunities for change; and transformation is concerned with the new service implementation. In line with this perception, the models of new service development, service innovation, or service design can be seen as the dynamic capability of service innovation.

\section{Interaction Between DMC and SIC and Performance}

The relationship between innovation and marketing has been acknowledged (21), (1). In (13) showed that the effect of the combination of capabilities on results is greater, and complementary capabilities can increase a firm's effectiveness and/or efficiency (22), (1), (23). The studies to date have explored the effects of innovation and marketing capability, as well as their interaction on performance in manufacturing and service context. This study proposes that the interaction of DMC and SIC are determining factors for performance of the hotel.

\section{Marketing Communication}

Marketing communications is a means to express itself and show the actual positioning to customers. In (24), in service and consumer goods companies, shows the relationship between integrated marketing communication (IMC) performance (in terms of cross-functional strategic planning, inter activity, and mission marketing) and market performance (brand advantage, customer satisfaction, and sales performance). The study that focused in the Croatian hotel industry mention that marketing effectiveness is positively associated with the performance level, the scope of marketing activities, the way marketing information is used in strategic and operational management and also with the status of the marketing department within the hotel company. The marketing activities consist of advertising, promotional materials and PR that correlated with hotel performance in terms of occupancy rate and revenue per available bed.

The study of marketing-finance interface could be a way to improve the relationship marketing communication and performance. In (25) mention that in tourism and hospitality industries which include airlines, hotels and restaurants there are positive marketing efforts contributed to the firms' financial performance. Marketing efforts are measured by advertising expense and consumer satisfaction score while the firm's performance is measured by ROE, ROA, PM, stock return, and Tobin's q. The analyses reveal that IMC practices (integration of marketing communication function between company and advertising agencies) vary across firm size, industry type, product/service orientation, and customer orientation. According to (26) in Nigeria conducted research of the effectiveness of advertising and personal selling practices of service companies in order to improve the existing communication and customer satisfaction. They concluded that advertising and personal selling indicated moderately effective in providing information, creating awareness, and changing attitude and ineffective in building company image and enforcing brand loyalty. The research also identified the lack of integration between advertising and personal selling. According to Nykiel in (27) stated that the hospitality industry has developed many different marketing communication concepts. Marketing communication has become a major contributor to driving occupancy or providing market advantage. In (28) conducted a study in Albania hotel industry concluded that the marketing communication was used in the hotel industry to improve how to act and to survive in a tight competitive market. Their study is enhanced by (29) in Albanian reality business to measure the effectiveness of marketing communication with performance, but their study was not specifically conducted in the hospitality industry. The hotel industry determines pro-motion based on their clients and their area of operation and tends to attract more customers from regional markets, national, and international. Refer to (29) in his research on Croatia hotels, said that promotion can help differentiate the product from other similar products that already exist in the tourist market (30). Each hotel has to find its way of pro-motion and figure out its unique and recognizable design. In (30) based on their study in the hotels and resorts in Chiang Mai, Thailand, mentioned that the tools of promotion that commonly used are printed media, local radio, brochures distribution and bill-boards nearby. Refer to (31) conducted a study of price-based promotional techniques at tourism and travel markets, but there is growing awareness that non-price based promotions can add value for the consumer while meeting a range of marketing communications objectives. One of the non-price promotional tools is the use of consumer competitions. From the above studies conducted by researchers that ranging from marketing communication concepts, tools and techniques, this study will take the marketing communication mix in developing model. In (32) reveal that promotion strategies play a crucial role in the launch of new products to the market that help attract the customer's attention towards the new product in a market cluttered with similar products. Total advertising expenditures have been found to have a positive impact on the market entry studies. In the 21 st century marketplace, the ability to measure a combination of marketing communication activities may be more important than trying to choose the impact or influence of any single element. In the marketing arena in which the allocation of limited resources is critical, it is more important to find the best and most effective set of brand communication tools and activities, not just those who can most widely distributed at the lowest cost. In (33) re-applied the SCP (Structure-Conduct-Performance) paradigm to international tourist hotels industry in Taiwan through three simultaneous equations, market share, advertising and profitability. According to (34) stated the relationship between CSR activities (public relations) and financial performance in the 
hospitality context. This study examines different impacts of positive and negative CSR activities on financial performance of hotel, casino, restaurant and airline companies, theoretically based on positive and negative effects. Findings suggest mixed results across different industries and will contribute to companies' appropriate strategic decision-making for CSR activities by providing more precise information regarding the impacts of each directional CSR activity on financial performance. From the above reviews, the researcher came to the conclusion that there is a relationship between marketing communication and hotel performance.

\section{E. Hotel Performance}

In the hospitality industry, there are certain performance measures that are regarded as the most important ones. In the hotel industry, it used to be the occupancy rate. Occupancy rate is the number of rooms occupied divided by total number of rooms. However, this measure has been replaced to a large extent, since the introduction of yield or revenue management, by REVPAR (revenue per available room). In fact, due to the complexity of each operation, there are many more measures apart from these which are important. Some can apply to all operations in the industry, while other input or output measures are specific to certain sectors of the industry. Measuring organizational performance in service organizations is more complex than that of the manufacturing. The services company emphasizes more on customer relationships than short-term transactions. Service organizations such as hotels measure its performance on human capabilities and intangible assets. The financial indicators used by the hotel include operating income/profit, operating margin, return on investment (ROI), cost, revenue per available room (Rev-PAR). Rev-PAR is equivalent to the room revenue divided by the total available room or hotel occupancy average daily times. In other words, Rev-PAR reflects the performance of hotels in both occupancy and price. Another study found that profitability is a financial indicator mostly used by the hotels in addition to revenue and cost control. Performance variables measured in the hotel industry consist of two, i.e. objective and perception, because this industry is to commercialize the intangible experience. Objective performance variables consist of the occupancy per room, gross operating profits and gross operating profit per available room per day. In (35) studied hotel performance and market orientation in 201 international hotels and found that market orientation is positively associated with both judgmental measures of performance such as: service quality, customer satisfaction, and employee satisfaction, and objective measures of performance such as: occupancy rate, gross operating profit, and market share.

According to (36) in Taiwan tourist hotels examines the economic impact of tourism growth on the performance of the hotel. Company performance indicators consist of occupancy rate (OPR), return on assets (ROA), return on equity (ROE), stock return, and overall financial performance. The results show that both real GDP growth rate and the growth rate of foreign tourist arrivals are significant explanatory factors of the level of occupancy, however it is only the growth rate of foreign tourist arrivals which could explain the ROA and ROE. GDP real growth rate is a little more crucial than the rate of growth in foreign tourist arrivals in explaining the performance of the hotel industry in Taiwan. In (37) explore the performance measurement practices in the context of a five-star independent resort hotel in Northern Cyprus. Decision makers involved in this study consisted of employees, managers and regional executives. The findings indicate six main themes, which are grouped in business dynamics and overall performance, employee performance, customer satisfaction, financial performance, and innovative activities performance measures. In (38) used the panel regression tests to examine the response of hotel performance to international tourism development and crisis events in Taiwan. The hotel performance measurements are revenue (revenue per available room and occupancy rate), profitability (return on assets and return on equity) and stock performance. The result of this study is that the international tourism development (ITD), proxy by the growth of total inbound tourist arrivals, has a more direct influence on hotel sales and profitability than it does on hotel stock performance. According to (39) studied the relationship between customer orientation, entrepreneurship and innovativeness on hotel industry performance dimensions (i.e., profit goal achievement, sales goal achievement and ROI achievement) in Switzerland. All dimensions have supported the dimensions of hotel performance. In (40), discuss the impact of market orientation on business performance. The use of product innovativeness is proposed as a mediator of the influence of market orientation on business performance. Product innovativeness is defined along two dimensions: the use of new-to-the-firm and new-to-the-market products. Business performance is represented by relative price premium, sales growth, capacity utilization, and profitability. The findings provide supports for the positive influence of market orientation on both dimensions of product innovativeness. However, it was only the use of the new-to-the-market products that turns out to give a positive contributor to the business performance.

\section{F. Hotel Industry in Indonesia}

The hotel industry in Indonesia has shown significant growth and has gained greater attention in today's business environment. The average growth rate of GDP in the hotel industry during 2004-2011 was 6.39 percent (www.bps.go.id) based on year 2000 constant price, compared to total Gross Domestic Product (GDP) at 5.84 percent. The hospitality sector became important when the government decided to further push the service sector. The average contribution of the hotel sector to total GDP based on year 2000 constant price within the 2004-2011 period amounted to 0.70 percent. The hotel industry is closely related to tourism. The tourism industry contributes the number of tourists who inhabit the hotels. The Indonesian Central Bureau of Statistics (www.bps.go.id) reported that there were 4.59 million foreign tourists in 2004 which had increased to 7.65 million in 2011. 
The revenue from international visitors has increased from US\$ 4.80 billion in 2004 to US\$ 8.55 billion in 2011. A similar trend can be seen in the number of hotels and the room occupancy rate (ROR). In 2004 there were 1, 014 classified hotels (star hotels) and 9,847 non-classified hotels (non-star hotels). These numbers had increased to 1,489 classified hotels and 13,794 non-classified hotels in 2011. The room occupancy rate in 2004 for classified hotels was 44.98 percent and for non-classified hotels 28.33 percent and these had increased to 51.25 percent and 38.74 percent respectively in 2011.

Though growing, the Indonesian hotel industry is facing new challenges due to external and internal factors in a business environment that affects their service excellence. External factors include intense competition from competitors. According to the Chairman of Indonesian Hotels and Restaurants Association (PHRI) of West Java, Mr. Herman Muchtar (personal communication, 20 ${ }^{\text {th }}$ December 2015), the main issue related to the hospitality industry in Indonesia is the intense competition among star hotels and non-star hotels. This intense competition occurs because of the excess supply of hotels, regulations in terms of hotel development and service standards, and global competition where the hotels chains with an international network invest in new potential areas.

\section{CONCEPTUAL MODEL}

The conceptual framework consists of the linking of the factors involved in the research and constituted the conceptual model on how a theory or logical sense of a relationship is identified to the problem. The literature review which is explained in the previous performs the conceptual framework of this study as displayed in Figure 1. This research will explore and examines the relationship between the variables of dynamic marketing capability, service innovation capability, marketing communication, and hotel performance.

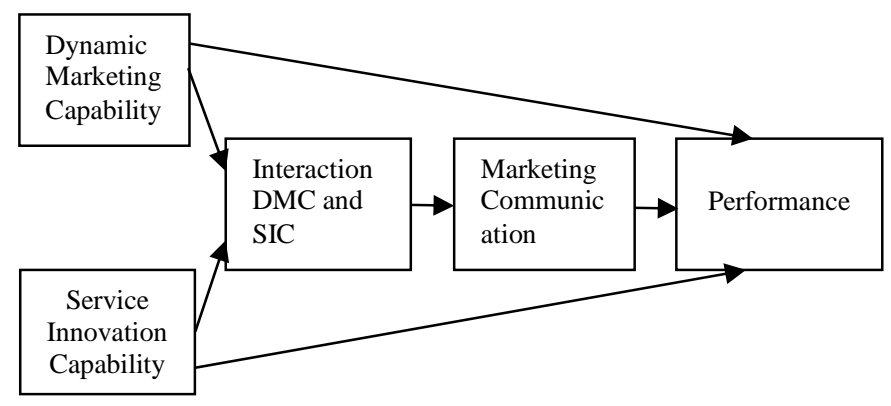

Fig. 1. Conceptual Model

The main focus of the conceptual model would be in integrating component of dynamic marketing capability, service innovation capability and marketing communication mix in order to achieve the better performance in the hotel industry, and exploring the intensity of service innovation, dynamic marketing and marketing communication mix and influence on hotel performance. Dynamic marketing capability and service innovation capability must be integrated with marketing communication to deliver the messages to the customers. The type of service innovation is being conducted in the companies included product, process, market, organizational, customization, and usage of IT should be communicated using the communication mix to the customer in order to enhance the awareness. Product-related factors: product advantage, technical quality, functional quality and innovative technology. The process dimension includes five aspects: pre-launch activities, employee involvement in the new service development process, launch preparation, effective marketing communication and NSD process management. Market features of the conceptual model are market synergy, market attractiveness and competition. Reputation, overall synergy, strategic human resource management, selective staffing, training of employees, behavior-based evaluation, empowerment and formalization represent the organizational dimension of the conceptual model. Another example of innovation in hotel services is the use of information technology. In (41) conducted one study that determined which of the recent technological innovations were most beneficial, least beneficial, and had future benefits for hotels. The most beneficial included: a wake up system, electronic door locks, in-room pay-per-view, video cassette players, multiple phone lines, video library, personal computers, voice mail, computer modem connections, video check out, electronic in-room safes, and a software library. Customizing the service experience for hotel guests is another means of service innovation. Some examples of service customization include: allowing guests to have flexible check in/out times, personalizing room decor, or having child care options available. Customized options adapt the hotel's service offering to each individual guest's preferences. However, customization is not easy to implement due to the operational capabilities of the firm. For example, a flexible check in/out policy could lead to labor scheduling problems. Adding such a policy successfully requires the alignment of hotel's marketing and operational activities (42). The marketing communication dimension mix according to (43).

\section{CONCLUSIONS}

It is expected that this study will contribute to the development of conceptual model that relate dynamic marketing capability, service innovation capability and marketing communication by involving the intensity of both aspects in the hotel industry. For the practice, this study aims at helping hospitality industries to better plan and move towards effective and intense marketing communication and greater service innovation implementation and practices which would assist hospitality industry to create the appropriate environment to encourage and promote customer satisfaction. For the government as a policy maker to in-crease the tourism sector specially to improve the regulations related to hotel business. This study will be the empirical research of the involvement marketing communication mix in service innovation, specifically studying the hospitality industry and that focuses on integration of IMC (integrated marketing communication) component. Furthermore, the study will investigate several dimensions in service innovation. These aspects reflect recent new insights from services marketing research. Hospitality organizations have to continuously 
develop new services in order to be successful and the results of these and further investigations will be of potential value to hospitality mangers, as it will enable them to focus on NSD (new service development) more strategically and professionally. The future research will be conducted firstly by gaining the new dimensions from experts in hospitality industries in Indonesia from PHRI (Persatuan Hotel dan Restauran Indonesia). The research will use the case study from selected hotels ranging from 3-star up to 5-star local, joint venture, and franchising in order to build the hypotheses in the preliminary stage. After that, the hypotheses will be tested formally in selected area in Indonesia using the structural equation modeling. The weakness of the current model is involving the marketing communication mix separately and not integrated. The future research will try to explore the combination of the elements in marketing mix according to the size, type of ownership, and star classification.

\section{REFERENCES}

[1] Moorman C, Slotegraaf RJ. The contingency value of complementary capabilities in product development. Journal of Marketing Research. 1999:239-57.

[2] Atuahene-Gima K. Market orientation and innovation. Journal of business research. 1996;35(2):93-103.

[3] Ngo LV, O'Cass A. In search of innovation and customer-related performance superiority: The role of market orientation, marketing capability, and innovation capability interactions. Journal of Product Innovation Management. 2012;29(5):861-77.

[4] Tushman ML. Winning through innovation. Strategy \& Leadership. 1997;25(4):14-9.

[5] Song M, Droge C, Hanvanich S, Calantone R. Marketing and technology resource complementarity: An analysis of their interaction effect in two environmental contexts. Strategic management journal. 2005;26(3):259-76.

[6] O'Cass A, Ngo LV. Winning through innovation and marketing: Lessons from Australia and Vietnam. Industrial marketing management. 2011;40(8):1319-29.

[7] Sok P, O'Cass A. Examining the interactive roles of marketing, innovation and social networking capabilities on firms customer-based performance| NOVA. The University of Newcastle's Digital Repository. 2010.

[8] Sok P, O'Cass A. Achieving superior innovation-based performance outcomes in SMEs through innovation resource-capability complementarity. Industrial Marketing Management. 2011;40(8):128593.

[9] Henard DH, Szymanski DM. Why some new products are more successful than others. Journal of marketing Research. 2001;38(3):36275.

[10] Im S, Workman Jr JP. Market orientation, creativity, and new product performance in high-technology firms. Journal of marketing. 2004;68(2):114-32.

[11] Day GS. The capabilities of market-driven organizations. the Journal of Marketing. 1994:37-52.

[12] Dutta S, Narasimhan O, Rajiv S. Success in high-technology markets: Is marketing capability critical? Marketing Science. 1999;18(4):547-68.

[13] Vorhies DW, Morgan NA. Benchmarking marketing capabilities for sustainable competitive advantage. Journal of marketing. 2005;69(1):80-94.

[14] Narasimhan O, Rajiv S, Dutta S. Absorptive capacity in hightechnology markets: The competitive advantage of the haves. Marketing Science. 2006;25(5):510-24.
[15] Bruni DS, Verona G. Dynamic marketing capabilities in Science-based firms: An exploratory investigation of the pharmaceutical industry. British Journal of management. 2009;20(s1):S101-S17.

[16] Teece DJ, Pisano G, Shuen A. Dynamic capabilities and strategic management. Strategic management journal. 1997:509-33.

[17] Fang EE, Zou S. Antecedents and consequences of marketing dynamic capabilities in international joint ventures. Journal of International Business Studies. 2009;40(5):742-61.

[18] Wilkinson A, Dainty A, Neely A, Brax SA, Jonsson K. Developing integrated solution offerings for remote diagnostics: A comparative case study of two manufacturers. International Journal of Operations \& Production Management. 2009;29(5):539-60.

[19] Gadrey J, Gallouj F, Weinstein O. New modes of innovation: how services benefit industry. International journal of service industry management. 1995;6(3):4-16.

[20] Pöppelbuß J, Plattfaut R, Ortbach K, Malsbender A, Voigt M, Niehaves B, et al., editors. Service innovation capability: Proposing a new framework. Computer Science and Information Systems (FedCSIS), 2011 Federated Conference on; 2011: IEEE.

[21] Drucker PF. The Practice of Management: A Study of the Most Important Function in America Society: Harper \& Brothers; 1954.

[22] Milgrom P, Roberts J. The economics of modern manufacturing: Technology, strategy, and organization. The American Economic Review. 1990:511-28.

[23] King DR, Slotegraaf RJ, Kesner I. Performance implications of firm resource interactions in the acquisition of $R \& D$-intensive firms. Organization Science. 2008;19(2):327-40.

[24] Reid M. Performance auditing of integrated marketing communication (IMC) actions and outcomes. Journal of Advertising. 2005;34(4):41-54.

[25] Denizci B, Li XR. Linking marketing efforts to financial outcome: An exploratory study in tourism and hospitality contexts. Journal of Hospitality \& Tourism Research. 2009;33(2):211-26.

[26] Akinyele S, Olorunleke K. Evaluation of effectiveness of marketing communication mix elements in Nigerian service sector. Pakistan Jownal of Social Sciences. 2010;7(2):76-80.

[27] Hariandja ES. The Relationship Between Service Innovation, Marketing Communication, and Performance in Hospitality IndustriesA Conceptual Framework. Proceeding of Industrial Engineering and Service Science. 2011:20-1.

[28] PJERO E, SHYLE I, editors. Promotion and hospitality industry: Albania as a case study. Marketing and Management Sciences: Proceedings of the International Conference on ICMMS 2008; 2010: World Scientific.

[29] Mateljić SR, editor Promotion and design in the hotel industry. Tourism \& Hospitality Management, Conference Proceedings; 2010.

[30] Sangkaworn C, Mujtaba BG. Marketing practices of hotels and resorts in ChiangMai: a study of products, pricing, and promotional practices. Journal of Management and Marketing Research. 2010;4:1.

[31] Peattie K, Peattie S. Promotional competitions: A winning tool for tourism marketing. Tourism Management. 1996;17(6):433-42.

[32] Vel KP, Sharma R. Megamarketing an event using integrated marketing communications: the success story of TMH. Business strategy series. 2010;11(6):371-82.

[33] Tung G-S, Lin C-Y, Wang C-Y. The market structure, conduct and performance paradigm re-applied to the international tourist hotel industry. African Journal of Business Management. 2010;4(6):1116.

[34] Kang KH, Lee S, Huh C. Impacts of positive and negative corporate social responsibility activities on company performance in the hospitality industry. International Journal of Hospitality Management. 2010;29(1):72-82.

[35] Agarwal S, Krishna Erramilli M, Dev CS. Market orientation and performance in service firms: role of innovation. Journal of services marketing. 2003;17(1):68-82.

[36] Chen M-H. The response of hotel performance to international tourism development and crisis events. International Journal of Hospitality Management. 2011;30(1):200-12. 
[37] Haktanir M, Harris P. Performance measurement practice in an independent hotel context: A case study approach. International Journal of Contemporary Hospitality Management. 2005;17(1):39-50.

[38] Chen M-H. The economy, tourism growth and corporate performance in the Taiwanese hotel industry. Tourism Management. 2010;31(5):665-75.

[39] Tajeddini K. Effect of customer orientation and entrepreneurial orientation on innovativeness: Evidence from the hotel industry in Switzerland. Tourism Management. 2010;31(2):221-31.
[40] Sandvik IL, Sandvik K. The impact of market orientation on product innovativeness and business performance. International journal of Research in Marketing. 2003;20(4):355-76.

[41] Reid RD, Sandler M. The use of technology to improve service quality. The Cornell Hotel and Restaurant Administration Quarterly. 1992;33(3):68-73.

[42] van Riel AC, Victorino L, Verma R, Plaschka G, Dev C. Service innovation and customer choices in the hospitality industry. Managing Service Quality: An International Journal. 2005;15(6):555-76.

[43] Kotler P, Armstrong G. Principles of marketing 15th global edition: Pearson; 2013. 